The period of oestrogen treatment used by Mills et al. (1960) is too short to allow comparison.

The dose of oestrogen used in the present work was sufficient to cause an increase in corticosteroid-binding globulin concentration, as judged by total cortisol levels. This dose is equivalent to slightly less diethylstilboestrol than that causing maximum corticosteroid-binding globulin increment (Doe et al., 1967). Therefore oral contraceptives may not cause so great an increase in unbound cortisol as, for example, the high doses of oestrogen used in the treatment of prostatic carcinoma.

The skewed distribution of both total and unbound cortisol in normal subjects explains the similar distribution of urinary cortisol found by Cope and Black (1959). Many plasma constituents are distributed in this way (Wootton, 1964), and the distribution must be taken into account when calculating the mean of a range of values (Gaddum, 1945). This also may be a factor in the disparity of some previous estimates of unbound cortisol.

I am indebted to Professor T. Russell Fraser and to Dr. C. L. Cope for both support and criticism. This work was carried out during the tenure of a Medical Research Counoil grant.
REFERENCES

Beardwell, C. G., Burke, C. W., and Cope, C. L. (1968). Fournal of Endocrinology, 42, 79.

Burke, C. W. (1969). Biochimica et Biophysica Acta, 176, 403

Cope, C. L., and Black, E. G. (1959). British Medical fournal, 2, 1117.

Doe, R. P., Fernandez, R., and Seal, U. S. (1964). Fournal of Clinical Endocrinology and Metabolism, 24, 1029.

Doe, R. P., Mellinger, G. T., Swaim, W. R., and Seal, U. S. (1967). Fournal of Clinical Endocrinology and Metabolism, 27, 1081.

Doe, R. P., Zinneman, H. H., Flink, E. B., and Ulstrom R. A. (1960). fournal of Clinical Endocrinology and Metabolism, 20, 1484.

Gaddum, J. H. (1945). Nature, 156, 463.

Layne, D. S., Meyer, C. J., Vaishwanar, P. S., and Pincus, G. (1962). fournal of Clinical Endocrinology and Metabolism, 22, 107.

Matsui, N., and Plager, J. E. (1966). Endocrinology, 78, 1159.

Mills, I. H., Schedl, H. P., Chen, P. S., and Bartter, F. C. (1960). fournal of Clinical Endocrinology and Metabolism, 20, 515

Murphy, B. E. P. (1967). Fournal of Clinical Endocrinology and Metabolism, 27, 973 .

Murray, D. (1967). Fournal of Endocrinology, 39, 571.

Peterson, R. E., Nokes, G., Chen, P. S., and Black, R. L. (1960). Fournal of Clinical Endocrinology and Metabolism, 20, 495 .

Plager, J. E., Schmidt, K. G., and Staubitz, W. J. (1964). Fournal of Clinical Investigation, 43, 1066.

Sandberg, A. A., Rosenthal, H., and Slaunwhite, W. R. (1967). Proceedings of Second International Congress on Hormonal Steroids, edited by L. Martini, p. 707. Amsterdam, Excerpta Medica Foundation.

Sandberg, A. A., and Slaunwhite, W. R. (1959). Fournal of Clinical Investigation, 38, 1290.

Slaunwhite, W. R., Lockie, G. N., Back, N., and Sandberg, A. A. (1962). Science, 135, 1062 .

Wootton, I. D. P. (1964). In Microanalysis in Medical Biochemistry, 4th ed., edited by I. D. P. Wootton, p. 3. London, Churchill.

\title{
Studies in a Patient with Acute Leukaemia after Lysergide Treatment
}

\author{
O. MARGARET GARSON,* M.B., B.S.; MERYL K. ROBSON, $\dagger$ M.SC.
}

\begin{abstract}
Cummary : The second case of acute leukaemia develop$\checkmark$ ing after administration of lysergide is reported. The unusual bone-marrow chromosome pattern and the presence of large cells containing multiple micronucleoli suggest that this association may be causal.
\end{abstract}

\section{Introduction}

Cohen et al. (1967a) first reported that the addition of lysergic acid diethylamide (lysergide) to cultured human leucocytes resulted in a noticeable increase in chromosomal abnormalities. They also found similar abnormalities in the lymphocytes of a patient treated extensively with the drug. Since that time there have been a number of reports confirming these observations (Irwin and Egozcue, 1967 ; Cohen et al., 1967b ; Jarvik and Kato, 1968 ; Nielsen et al., 1968 ; Hungerford et al., 1968), and only two reports (Loughman et al., 1967 ; Sato and Pergament, 1968) where no abnormalities were found.

Data are accumulating on the occurrence of congenitally malformed children born to parents who had taken lysergide during pregnancy. (Zellweger et al., 1967 ; Hecht et al., 1968). Egozcue et al. (1968) found a " $\mathrm{Ph}^{1}$-like" chromosome in three users of the drug and in the progeny of four others, and Grossbard et al. (1968) reported the case of a patient with acute leukaemia and a " $\mathrm{Ph}^{1}$-like" chromosome, who had been

* Research Fellow.

t Research Assistant.

University of Melbourne Department of Medicine, St. Vincent's Hospital, Melbourne, 3065, Australia. taking lysergide. Hence there is probably sufficient evidence to suggest a relationship between lysergide and chromosome abnormalities. The occurrence of these chromosome abnormalities may also imply a possible leukaemogenic effect, similar to the situation that exists in Bloom's syndrome (Sawitsky et al., 1966) and Fanconi's anaemia (Bloom et al., 1966). While the significance of these abnormalities is uncertain, it is important to report any case in which lysergide administration has been followed by the occurrence of either leukaemia or congenital malformation. This communication reports the cytogenetic studies performed on a patient who had been given injections of lysergide for a depressive state and who subsequently developed acute lymphoblastic leukaemia.

\section{Case Report}

The patient, a man aged 23, first presented in October 1968 with a 12-month history of increasing tiredness and a more recent onset of pallor. Two months before admission he had a severe "influenza-like illness" followed by low back pain. One week before admission he developed bleeding gums and a petechial rash over both legs. He was a tall, pale young man with marked sternal tenderness; the spleen was palpable $7 \mathrm{~cm}$. and the liver $5 \mathrm{~cm}$. below left and night costal margins, respectively. There was slight enlargement of the inguinal lymph nodes. On admission his haemoglobin was $11.2 \mathrm{~g} . / 100 \mathrm{ml}$., the white cell count $4,000 /$ cu. mm., with $25 \%$ blast cells, and a platelet count $12,000 /$ cu. $\mathrm{mm}$. Bone-marrow aspiration produced a hypercellular marrow showing $90 \%$ blast cells, thought to be lymphoblastic in type. Treatment was begun with prednisolone $60 \mathrm{mg}$. daily and three 
injections of rubidomyoin (160 mg. each) over a period of nine days. A bone-marrow examination three weeks after admission showed a reduction in blast cells to $20 \%$ and a great increase in erythroid elements, suggesting that remission was starting. This was achieved and the patient has continued in remission for four months, being maintained on mercaptopurine.

The past history showed that 12 months before the leukaemia was diagnosed he had sought psychiatric advice for an obsessive compulsive neurosis for which he had been given lysergide. The regimen of administration and dosage of lysergide are shown in Table I. The last of the injections was given eight months before acute leukaemia was diagnosed.

\begin{tabular}{c|c|c}
\multicolumn{3}{c}{ TABLE I.-Dosage of Lysergide } \\
\hline Date & Route of Administration & Amount of Lysergide given \\
\hline $8 / 11 / 67$ & Intramuscular & $9 \mathrm{mg.}{ }^{*}$ \\
$22 / 11 / 67$ & Intramuscular & $100 \mu \mathrm{g}$. \\
$22 / 11 / 67$ & Intravenous & $50 \mu \mathrm{g}$. \\
$6 / 12 / 67$ & Intramuscular & $200 \mu \mathrm{g}$. \\
$20 / 12 / 67$ & Intramuscular & $300 \mu \mathrm{g}$. \\
$28 / 2 / 68$ & Intramuscular & $200 \mu \mathrm{g}$. \\
\hline
\end{tabular}

The family history (pedigree, see Diagram) showed that the mother had had 10 pregnancies, three of whioh terminated in miscarriages at three to three and a half months. Two sisters, II 4 and II 5, died with malignancies before the third year of life ; II 4 with a suprarenal tumour and II 5 with a cerebral tumour. In addition, II 1 is a deaf mute following maternal rubella, II 2 had mumps encephalitis in childhood, and II 6 had Haemophilus influenzae meningitis at the age of 2 years.

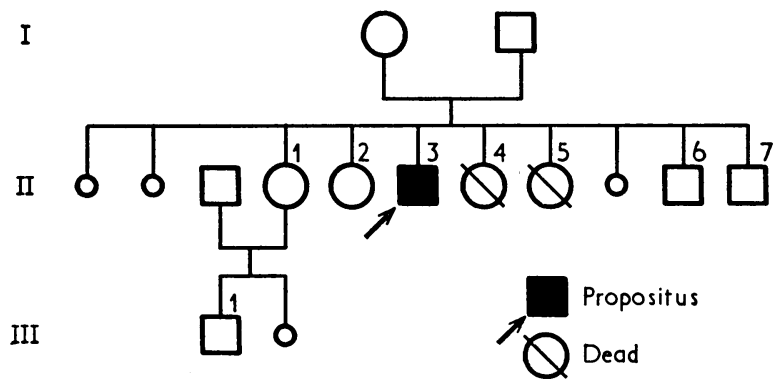

Pedigree of patient.

\section{Methods}

Bone-marrow chromosome examinations were performed by a modification of the direct method of Kiossoglou et al. (1964). Lymphocyte mitoses were prepared from a three-day phytohaemagglutinin-stimulated culture by the method of Turner et al. (1962). Chromosome abnormalities were scored as chromatid and isochromatid gaps and/or breaks, and hyperdiploid cells.

\section{Results}

Bone-marrow chromosomes obtained from the first marrow aspiration showed an unusual pattern and morphology. In general the chromosomes were extremely contracted and the chromatids widely separated, making accurate counting and analysing impossible. However, from general cell size under low power $(\times 10)$ three sizes of cells could be seen, and in a total of 190 cells thus scored a ratio of 95 small:24 intermediate:71 large cells was present. Several analysable cells in each group enabled the number of chromosomes per cell to be identified as (a) hypodiploid $(2 \mathrm{~N}=36$, chromosomes missing from all groups except group D), (b) normal diploid $(46, \mathrm{XY})$, and (c) polyploid $(4 \mathrm{~N}, 6 \mathrm{~N}$, with $2 \mathrm{~N}=36)$. A total of 12 cells were capable of analysis and no chromatid breaks or gaps were seen.

A bone-marrow aspiration 17 days later, when the patient was beginning remission, showed the distribution of structural chromosomal abnormalities given in Table II. In contrast to the previous marrow, there were many good mitoses with normally contracted chromosomes capable of analysis. The patient was found to be in cytogenetic remission at this time; the modal number of chromosomes being 46 with constitution $46, \mathrm{XY}$.

TABLE II.-Distribution of Chromosomal Abnormalities in Bone Marrow and Lymphocytes

\begin{tabular}{|c|c|c|c|c|c|c|c|c|c|}
\hline \multirow[b]{2}{*}{ Tissue } & \multirow{2}{*}{$\begin{array}{c}\text { Total } \\
\text { Cells } \\
\text { Exam- } \\
\text { ined }\end{array}$} & \multicolumn{3}{|c|}{ Gaps } & \multicolumn{3}{|c|}{ Breaks } & \multicolumn{2}{|c|}{$\begin{array}{c}\text { Hyperdiploid } \\
\text { Cells }\end{array}$} \\
\hline & & C. & I. & $\begin{array}{l}\text { Total } \\
(\%)\end{array}$ & C. & I. & $\begin{array}{c}\text { Total } \\
(\%)\end{array}$ & Total & $\%$ \\
\hline $\begin{array}{l}\text { Bone marrow } \\
24 / 10 / 68 \\
\end{array}$ & 65 & 2 & - & $3 \cdot 2$ & 1 & 2 & $4 \cdot 8$ & 一 & - \\
\hline $\begin{array}{l}\text { Lympnocytes } \\
10 / 10 / 68 \\
\text { Lymphocytes }\end{array}$ & 200 & 19 & 22 & 20.5 & 4 & 12 & 8.0 & 2 & $1 \cdot 0$ \\
\hline $\begin{array}{l}\text { (Nelsen et } \\
\text { al., 1967) }\end{array}$ & 358 & 12 & $4 \overline{5}$ & $15 \cdot 9$ & 5 & 1 & 1.7 & 7 & $2 \cdot 0$ \\
\hline
\end{tabular}

A three-day phytohaemagglutinin-stimulated blood culture performed one week after admission showed an abundance of gaps and breaks (Table II).

Chromosome studies in both parents (Table III) showed that in both cases the modal number of chromosomes per cell was 46 , and on detailed graphic analysis the chromosome constitution was normal female $(46, \mathrm{XX})$ and normal male $(46, \mathrm{XY})$ respectively. The hypodiploid cells showed a random chromosome loss, and no abnormal cell lines were present.

TABLE III.-Chromosome Counts of Parents

\begin{tabular}{|c|c|c|c|c|c|}
\hline \multirow[b]{2}{*}{4} & & \multicolumn{3}{|c|}{ No. of Chromosomes per Cell } & \multirow{2}{*}{$\begin{array}{c}\text { Total } \\
\text { No. of Cells } \\
\text { Counted }\end{array}$} \\
\hline & & $<45$ & 45 & 46 & \\
\hline $\begin{array}{l}\text { Mother } \\
\text { Father }\end{array}$ & $\therefore$ & $\begin{array}{l}2 \\
1\end{array}$ & $\begin{array}{l}7 \\
6\end{array}$ & $\begin{array}{l}36 \\
31\end{array}$ & $\begin{array}{l}45 \\
38\end{array}$ \\
\hline
\end{tabular}

\section{Discussion}

The occurrence of either transient or persistent chromosome abnormalities following the administration of lysergide has been shown by a number of workers (Cohen et al., 1967b); Egozcue et al., 1968 ; Hungerford et al., 1968). These abnormalities are similar to those described following irradiation of the spine in patients with ankylosing spondylitis, in whom the average mortality from acute leukaemia is increased tenfold (Buckton et al., 1962). Chromosome aberrations are also present in Bloom's syndrome and Fanconi's anaemia, in both of which the incidence of acute leukaemia is significantly increased (Sawitsky et al., 1966; Garriga and Crosby, 1959). Thus the possibility of lysergide being a leukaemogenic agent is raised. The finding of a " $\mathrm{Ph}^{1}$-like" chromosome by Egozcue et al. (1968) in seven patients-three adult users of the drug and four babies born to mothers who had taken lysergide during pregnancy-and the description by Grossbard et al. (1968) of a patient with acute myeloblastic leukaemia following the ingestion of lysergide, tend to support this possibility. Our patient is the second reported case of acute leukaemia occurring after lysergide administration. He differs from the patient described by Grossbard et al. in that the lysergide was given therapeutically, the leukaemia is lymphoblastic in type, and a " $\mathrm{Ph}^{1}$-like" chromosome was not present.

The association between the ingestion of lysergide and the occurrence of acute leukaemia may be casual rather than causal, but certain unusual features in our case suggest that it may be causal. Thus the chromosome pattern in the bone-marrow cells is very unusual and differs appreciably from the hyperdiploid pattern which is commonly found in acute lymphoblastic leukaemia (Sandberg et al., 1968). In addition, large cells containing multiple micronucleoli were noted in the patient's bone marrow, apparently similar to the cells described by Loughman et al. (1967) as occurring in lysergide users. Our patient's family history shows a remarkable incidence of childhood malignancies and severe viral infections; this could suggest the possibility of a familial predilection to malignancy ; nevertheless, there were no chromosomal abnormalities demonstrated in either parent. 
The chromosome aberrations-for example, gaps, breaks, and fragments-present in our patient's second bone-marrow examination, taken in remission, and in the stimulated lymphocyte culture are of uncertain significance; the bone-marrow changes may have been due to the rubidomycin, but the lymphocyte changes could well be due to the lysergide. Thus we have found that similar abnormalities in bone-marrow chromosomes occur after a course of rubidomycin therapy (unpublished observations). Nevertheless, as only a few hours had elapsed between the administration of the first injection of rubidomycin and the preparation of the lymphocyte culture, it may be that the aberrations detected in the lymphocytes are a lysergide effect.

On the basis of the findings reported in this and other communications it is suggested that cases of leukaemia that follow administration of lysergide be reported, preferably with cytogenetic studies, as this may allow an appraisal of the possible relationship between lysergide and leukaemogenesis.

We wish to thank Professor G. C. de Gruchy for his helpful advice and comments.

This work was supported by a grant from the Herman Bequest. One of us (O.M. G.) was supported by a grant from the AntiCancer Council of Victoria.

\section{REFERENCES}

Bloom, G. E., Warner, S., Gerald, P. S.., and Diamond, L. K. (1966) New England fournal of Medicine, 274,8.

Buckton, K. E., Jacobs, P. A., Brown, W. M. C., and Doll, R. (1962) Lancet, 2, 676.

Cohen, M. M., Marinello, M. J., and Back, N. (1967a). Science, 155, 1417

Cohen, M. M., Hirschhorn, K., and Frosch, W. A. (1967b). New England fournal of Medicine, 277, 1043

Egozcue, J., Irwin, S., and Maruffo, C. A. (1968). Fournal of the American Medical Association, 204, 214.

Garriga, S., and Crosby, W. H. (1959). Blood, 14, 1008.

Grossbard, L., Rosen, D., McGilvray, E., de Capoa, A., Miller, O., and Bank, A.' (1968). Fournal of the American Medical Association, 205, 791 .

Hecht, F., Beals, R. K., Lees, M. H., Jolly, H., and Roberts, P. (1968). Lancet, 2, 1087.

Hungerford, D. A., Taylor, K. M., Shagass, C., LaBadie, G. U., Balaban, G. B., and Paton, G. R. (1968). Fournal of the American Medical Association, 206, 2287.

Irwin, S., and Egozcue, J. (1967). Science, 157, 313.

Jarvik, L. F., and Kato, T. (1968). Lancet, 1, 250.

Kiossoglou, K. A., Mitus, W. J., and Dameshek, W. (1964). American

fournal of Clinical Pathology, 41, 183. Science, 158, 508 .

Science, 158, 508.
Nielsen, J., Friedrich, U., Jacobsen, E., and Tsuboi, T. (1968). British Medical fournal, 2, 801 .

Sandberg, A. A., Takagi, N., Sofuni, T., and Crosswhite, L. H. (1968). Cancer, 22, 1268.

Sato, H., and Pergament, E. (1968). Lancet, 1, 639.

Sawitsky, A., Bloom, D., and German, J. (1966). Annals of Internal Medicine, 65, 487.

Turner, B., den Dulk, G. M., and Thompson, W. C. (1962). Medical fournal of Australia, 1, 893.

Zellweger, H., McDonald, J. S., and Abbo, G. (1967). Lancet, 2, 1066.

\title{
Diagnosis of Deep-vein Thrombosis with an Ultrasonic Doppler Technique
}

\author{
D. S. EVANS,* M.B., B.S., F.R.C.S. ; F. B. COCKETT, † M.S., F.R.C.S.
}

British Medical fournal, 1969, 2, 802-804

\begin{abstract}
Summary : An ultrasonic technique has been used to $\checkmark$ diagnose deep-vein thrombosis, the venous system being examined from the calf to the inferior vena cava. The method is quick, simple, and repeatable, and the results compare favourably with those from phlebography.
\end{abstract}

\section{Introduction}

The clinical diagnosis of deep-vein thrombosis in the early stages when there is a risk of massive pulmonary embolism is notoriously difficult and inaccurate. Currently the methods available for confirmation of a suspected diagnosis are phlebography and in some centres isotopic studies. Strandness et al. (1967) and Sigel et al. (1968) reported experience with an ultrasonic method incorporating the Doppler principle for the diagnosis of peripheral thrombosis, which promised to be simple, inexpensive, and reliable. We have further extended this use and now report our early experience based on this principle.

\section{Technique}

Apparatus.-A portable battery-run Sonicaid machine independent of mains supply operating at 2 megahertz $(\mathrm{MHz})$ was used. This consisted of a power generator and amplifier con- nected by a lead to a transducer containing two piezoelectric crystals. A controlled squeeze was applied to the calf by means of a cuff which could be rapidly inflated. If in addition to the audible signal permanent visual recordings were required a standard two-channel recording machine was used.

Principle.-The transducer containing two piezoelectric crystals were applied to the skin overlying the vessel to be examined, olive oil being used as a coupling medium. One crystal acted as a source of ultrasound and the other as a receiver. When the transducer was applied over a vein a faint noise was heard from the amplifier, due to sound reflected from the blood passing along the vein. If the velocity of blood flow in the vein was accelerated more blood passed through the ultrasonic beam and caused a change of frequency and amplitude of the sound to be picked up by the receiving crystal. In a normal leg augmentation of velocity of flow by squeezing the thigh or calf produced an easily audible roar from the amplifier. With a recent venous occlusion there was either little or no augmentation of venous return and no corresponding response from the ultrasonic detector.

The ultrasonic response to increased venous flow has been termed the "A" wave by Sigel.

* Research Assistant.

t Consultant Surgeon.

Vascular Laboratory, St. Thomas's Hospital, London S.E.1. 